\title{
Perspectives of Student in Self-Directed Language Learning at Nursing Department Polytechnic of Health of Denpasar
}

\author{
I Made Juliarta \\ Nursing Department, Polytechnic of Health of Denpasar \\ Denpasar, Indonesia \\ MadeJuliarta330@gmail.com
}

\begin{abstract}
This article describes the perspective of students in self directed language teaching. There are some benefits of self-directed learning viewed by the students. A teacher also has the role in giving feed back to students once they have finished doing the assignment given by the teacher. Although, the students do not receive much feedback, they use it as a suggestion to improve their English skills. The students are given assignments by their teachers to make English role play in which the role play is saved in soft copy. The data were collected from focus group students of foreign language because this assignment can lead them to improve their English skills. Wilcox (1996) stated that the basic tenets of self-directed learning, calling for personal autonomy and responsibility. Self-directed learning has been applied in many fields. Students were asked to tell story of their first experienced in doing job training in hospital. They wrote the experience in a paper and made a recorded video. In a video, they told the story of their first experience in doing job training in hospital. The assignments were given to students in order that the students can give their English skills by doing these assignments. The papers were submitted and the teacher gave correction on the mistakes found in the paper. Then, the students viewed the benefits of engaging in self-directed learning and the role of the teachers in self-directed learning. One student stated that the project enabled them to prioritize learning. This study has three research questions, those are: (1) what are the benefits of engaging in self-directed learning for the students. (2) what are the role of teachers in self-directed learning for the students.
\end{abstract}

Keywords-learning; students; language; assignments; training

\section{INTRODUCTION}

There is the rapid development of technology and fast pace of change which render professional knowledge by the time students graduate from institution. In addition, an important acquired competencies, such as foreign language, should be constant maintenance after students leave the classroom. Teachers can develop students self directed learning skills in order to make proggress on students skills in mastering English as their second language. Many institution has applied the self-directed learning (SDL) which is good for the students progress in astering English. There are the basic tenets of selfdirected learning, which call for personal autonomy and responsibility. Most of lectures in the educated institution argue that the development of self-directed learning skills is essential to improve by evaluating the learning needs of adult learners. There are few studies foregrounded as a major research focus students experiences of engaging in selfdirected learning. This study amis at analyzing how students view the benfits and roles of teachers in self-directed language learning.

This study is used to fill the void in current literature by examining the perspectives of a group of community college students in the Nursing department who participated in selfdirected language learning project. Self-directed language learning is a process in which individuals take the initiative, with or without the help of others, in diagnosing learning needs. There are some essential components of self-directed language learning. The teacher can be facilitator of learning; learners will be involved in identifying their learning needs. Self-directed language is primarily applied in adult formal education programs.

There are some various skills and attitudes which are needed for successful independent study. Students should understand themselves as learners in order to understand their needs as self-directed learning students. Students will be able to engage in self-direction and self evaluation of learning goals and progress in a unit of study. The students will be successful in independent study when they have certain responsibilities or roles both both students and and advising faculty members. Students should understand their approach to studying, those are: deep approach, surface approach, and strategic approach. It is importnat that the students need to generate their generations betwen their connection and their own motivators. Self-language learning can refer to any selfteaching projects in which the learners can make their specific goals, plan strategies, and maintain motivation to learn independently. It also can be a proccess to evaluate the learning progress with or without the help of others. Based on the explanation of self-directed language learning, this study investigates the role of teachers in self-directed learning and benefits for students. 


\section{LITERATURE REVIEW}

There is an international journal which are reviewed in this paper: Fengning (2013), in her paper entitled students perspective of self-directed language learning implications for teaching and research. This paper analyzed about a qualitative study examining students' perspectives of engaging in an autonomous learning project at a community college. How students view the benefits of SDL as well as the roles of the teachers. This study aims at describing how students of Chinese as a second language viewed the benefitd of engaging in self-directed learning, how they viewed the role of the teachers within the SDL format. There are some students who developed meta-cognitive skills such as the ability to prioritize tasks, indeendently locate the resources. Her paper also analyzed about the reading strategies through trial and error. There are some tasks given by the teachers to the students.

However, types of exercises help these students by going through something they could do at home. Students gave review on the process of learning how to study news independently. There are some similarities between fengning's paper and my paper. Those both papers are analyzing about students perspective and slef-diceted language learning. Meanwhile, the difference is that my paper specifically gives more comments on students. However, fengning's paper didn't give more specific on it.

\section{METHOD}

This study focuses on group interviews in order to explore the behaviors of individuals involved in a study. The researcher collects data from multiple individuals simultaneously. The interviewed group were conducted with twenty students. It is divided into four groups. The students are selected by the researcher based on their academic achievement levels as well as availabilities for interviews which were conducted in afterschool hours. All participants are ensured by the researcher to have an opportunity to respond to questions as well as to engage in spontaneous change.

There are some questions which were asked to the students. The first is that how does this project improve language proficiency. The second one is that how to view teacher feedback in the project. And the last one is that what teacher can do to improve feedback. The transcripts of the interviews were analyzed in accordance with the principles of inductive research. The researcher took a note of the transcripts said by the students. Then, the researcher established preliminary categories to represent each incident collected from the raw data. Each participant reviewed and confirmed the accuracy of developed categories, further enhancing the trustworthiness of the findings.

\section{RESULT}

This study aims at describing how students of English as a second language viewed the benefits of engaging in selfdirected learning. How they viewed the role of the teachers within self-directed language learning abilities. There are some benefits the students get from through participation in this project, including higher motivation, and improve selfdirected language learning.

\section{A. The Role of Teachers in Guiding the Students}

In this occasion, the researcher has a role as the teacher of this project, and gives generic feedback to the students. The researcher found some errors in the writing assignments, in the transcript of role play, and toast master. In addition, the researcher gave the assignments about topic of the role play in each submitted papers and gave feedback on them. The students have high expectations of one-on-one feedback with teachers. It can be seen from the examples that when the students gave feed back to the students, the teacher called the students one by one, then told them about the mistakes which was made while making the assignments of role play. The students, then took a note of some mistakes made by them and understood the revised transcripts of role play. It has the purpose that when they make another project of role play in the future, they can remember it well about the important of the vocabularies.

The students can go over sentence by sentence and translate it. The easiest way to learn is that the teacher can give evaluation directly to the students. The teacher corrected mistakes in front of the class. The students get the highest expectation to the teacher when they want to get feedback. Some students also want straight forward feedback. The teacher actually wants to know what they did wrong, and what they need to improve on. A student gave a comment:

"A teacher gave suggestions with the students for about 10 or 15 minutes. Then after doing evaluation, the teacher could circle any part of the mistakes. The student could remember the mistakes made by them. When they have any questions relating to the assignments they can ask it directly to the students."

\section{B. The Benefit of Self-Directed for Students}

This study aims at analyzing how English as a Second Language, student perceived both the benefits of engaging in self-direct language project and the role of the teachers within the self-directed language framework as well as factors contributing to variances in student self-directed language performance. The students get the benefits in areas of content knowledge, cognition, motivation, and self-directed language competencies.

In comparison to traditional teaching methods, selfdirected language learning was more effective in improving students' knowledge base and might be as effective in improving the skills and attitudes. All the students who took part in this project reported improvements in knowledge domain; for example, they claimed to have an increased understanding of the linguistic properties. Students also reported that there is an increased intrinsic motivation. There are some students in this study who developed a range of meta-cognitive skills such as the ability to prioritize learning tasks, locate resources independently and develop suitable reading strategies. Teaching methods must be matched to the learner's stage of direction. It was found that both prior slef- 
directed language experience and self-efficacy affected students initial comfort with self-directed language learning. The students can get several benefits by doing assignments in self-directed languag learning. They have opportunities to get to know each other if group learning is involved.

Teachers gauge students' affective attitudes toward selfdirected language learning to determine their initial comfort levels with the format. Teachers used questionnaire to measure critical variables affecting self-directed language learning success which include student readiness, learning styles, and psychology types. The collected data will help teachers to determine the initial degree to which they should structure the program, in accordance with self-directed language and design learning tasks that incorporate differences of learning styles. While giving understanding to the students, the teacher need to clearly communicate to the students the goals, learning activities, assessment criteria, schedule, available resources and roles of the teacher in the program.

First, the project afforded all participants to familiarize with the structure and linguistic properties in dialogue of English medical role play. One student gave comments,

"The lecture gave us assignment in making English role play video in order that the students can practice their medical English well. Therefore, when they will work in hospital, they will use their english daily conversation or medical English and their vocabularies. We did the conversation to our friends in English by doing acting in English".

The students then took a note of some important vocabularies they think that those vocabularies are often used in English medical conversation. They had to remember the contents of nursing english role play. They made the story about the deseases sufferred from the patients. One student is as a nurse, doctor, patient, family of the patients, and hospitals staffs. The students chose the topic of English medical role play. The students said that it is very useful to improve the English ability especially in mastering the medical Englsih terms.

The teacher also asked the students to present their topic in the form of toast master. Toast master is the form of english presentation in which the students presented their topic by using English. In this presentation of toast master, the student will act as a moderator, time keeper, leader, ah-counter, grammarian, and speech evaluator. One group of toast master consists of eight students. After the students presented their topic in toast master form, they gave the genefits of selfdirected language learning by doing the presentation of toast master. One student said:

"This form of presentation is very helpful as the students can practice their english and after all, the teacher or fasilitator gave comments or suggestion after we have finished doing the presentation in front of the class".

They don't forget to take a note of some difficult vocabularies they think that it is difficult for them. Then, the students tried to remember the english medical terms well in order that they can use it when they will work in hospital. They also tried to formulate realistic goals consistent with their emergent language levels. When the students delivered the speech in front of their friends, they can skim and find words they don't know and write them down. They could understand the articles or the text of the toastmaster in which they must deliver the speech without reading the text. In this case, they chose words based on frequency by picking out the recurring vocabulary they need to be able to understand the passage. The students chose the topic of the toastmaster freely.

The teacher also asked the students to write the experience in doing practice in hospital. They made the story telling about their experience while doing practice in hospital. They made for about 3 paragraphs and write it down in the paper. The purpose of this assignment is that the students can do the writing exercise meanwhile the teacher can give feedback after this. However, the students said that by doing this assignment, they can remember again their nice expereince they get while doing practice in hospital. One student commented:

"For me, by doing the assignment I can learn about the new vocabularies I get from this writing exercise. I can remember again the experience there. Before doing this writing exercise, I never had an interest in writing experience. It was just a good start for me into the habit in writing exeercise".

The students can develop their writing skills such as the ability in writing. They also make vocabulary lists. The students said that doing assignment in self-directed learning enhanced the students motivation and sense of personal accomplishment. A student reflected on the process of learning how to study role play independently:

"After I have finished doing role play the first one, I saw how helpful it is. It could give motivation to work hard to understand the scripts of role play".

Another student gave appreciation the freedom of choice in making the assignment. "I think it could give motivation whenever you have a free choice. The teacher asked me to make story. When I had some difficult vocabularies from Indonesian into English to be translated, then I took some note of those vocabularies as I thought that it was important vocabularies".

The students can feel it better when they have to do self-study and can make it faster by knowing exactly what to look for. They know what that means, and that would be from there. Their speaking skill can be improved by practicing English in toast master form. The students said that their speaking skills are improved by practicing English in toast master form. There are about ten students who continued to study the role play in mastering medical English, and demonstrating their acceptance of the value in learning a foreign language.

\section{CONCLUSION}

This study gave the explanation about the perspective of self-directed language learning project that focused on dialogue of role play, toast master presentation and telling experience in doing practice in hospital. Sel-directed language learning leads to improvements in knowledge domain (e.g., understanding vocabulary and english structure). A successful self-directed language program can be seen from a close alignment between contextual variables and specific learning 
tasks. Sekf-directed language program is the most effective instructional programs which are intended to transmit knowledge. The students can improve their ability especially in speaking, reading, and listening by doing English role play.

\section{REFERENCES}

[1] J. Bown, Self-regulatory strategies and agency in self- structured language learning, 2009.

[2] A situated view. The Modern Language Journal, vol 4 .pp. 570-583.

[3] P.C. Candy, Self-direction for life-long learning. San Francisco: JosseyBass, 1991.

[4] V. Chan, Autonomous language learning: "The teachers' perspectives. Teaching in Higher Education", vol 1, pp. 33-54. Oxford, R.L. (2003). Toward a more systematic model of L2 learner autonomy. In D. Palfreyman, \& R.C. Smith (Eds.). Learner autonomy across cultures: Language education perspectives, Hampshire: Palgrave Macmillan Ltd, pp. 75-91, 2003.

[5] P. Riley, Who's who in self-access. TESOL France News, vol 6, pp. 23$35,1986$. 